KATARZYNA GOLIK

Instytut Studiów Politycznych PAN

ORCID: 0000-0002-9161-8222

katarzyna.golik@isppan.waw.pl

\title{
Państwo jednego miasta - urbanizacja postnomadów i specyfika przestrzeni miejskiej
}

Recenzja książki Rebekah Plueckhahn pod tytułem Shaping Urban Futures in Mongolia: Ulaanbaatar, Dynamic Ownership and Economic Flux

\section{The state of one city: postnomad urbanisation and the specificity of urban space}

A review of a book entitled Shaping Urban Futures in Mongolia: Ulaanbaatar, Dynamic Ownership and Economic Flux by Rebekah Plueckhahn 

P

rocesy urbanizacyjne zachodzące w stolicy Mongolii, Ułan Bator, stanowią obiekt badań z co najmniej kilku powodów. Przede wszystkim mamy tu do czynienia z wyjątkowością procesu tworzenia miast. Osadnictwo postnomadów, i jego ewolucja, odzwierciedla cechy ich organizacji społecznej, bardzo słabo znanej w świecie euroatlantyckim. Z punktu widzenia organizacji państwa mamy do czynienia z układem centrycznym (podobnym do rosyjskiego), który manifestuje się m.in. w sytuacjach, gdy jeden ośrodek (lokalny lub państwowy) absorbuje nieproporcjonalnie dużo środków oraz wchłania silne fale migracji wewnętrznej. To zogniskowanie w jednym miejscu do pewnego stopnia ułatwia analizę, gdyż gros procesów urbanizacyjnych, ale i szerzej: społecznych, gospodarczych czy politycznych, odbywa się w jednym jego mieście. Biorąc pod uwagę aspekty gospodarcze, stanowi ono studium przypadku strukturalnych problemów państw posttransformacyjnych. Z tej przyczyny mongolska stolica nie musi być obiektem zainteresowania wyłącznie orientalistów. W wyniku badań przeprowadzonych przez University College London na temat urbanizacji ${ }^{1}$ powstała godna uwagi pozycja antropolożki Rebekah Plueckhahn poświęcona aktualnemu rozwojowi przestrzennemu i dynamice społecznej Ułan Bator.

Autorka posługiwała się metodą jakościową wywiadów bezpośrednich, które przeprowadziła $\mathrm{z}$ mieszkańcami miasta podczas 12-tygodniowych badań w latach 2015-2017 w ramach projektu badawczego w University College London, bazując również na kontaktach i doświadczeniach $\mathrm{z}$ prac nad rozprawą doktorską z lat 2009-2010 oraz wyjazdów do Mongolii z okresów wcześniejszych.

Podstawową formą metodyczną zastosowaną $\mathrm{w}$ tym badaniu były wywiady z mieszkańcami stolicy. Autorka nie ograniczyła się do rozmów z mieszkańcami, tworząc kronikę szans i wyzwań dla zwykłych ludzi, lecz przeprowadziła również wywiady z osobami tworzącymi nowy ład: urzędnikami, urbanistami i deweloperami. Dzięki temu mogła skonfrontować zapisy dokumentów z realną praktyką. Podejście metodyczne umożliwia analizę procesów nie tylko na poziomie instytucji oficjalnych, ale często pozwala także dotknąć realnych procesów, nie zawsze sformalizowanych.

1 Rebekah Plueckhahn, Shaping Urban Futures in Mongolia: Ulaanbaatar, Dynamic Ownership and Economic Flux, UCL Press, London 2020, DOI: https:// doi.org/10.14324/111.9781787351523. Książka w formacie pdf dostępna w internecie [dostęp: 27 IV 2021]: 〈https://www.uclpress.co.uk/products/95174〉. 


\section{Rozwój - od klasztoru do miasta}

Historyczny rozwój urbanistyczny na tym obszarze na początku XX wieku nie opierał się na trwałym osadnictwie, ale na dwóch stabilnych ośrodkach, z których każdy wyznaczał swoisty azymut: klasztorze ${ }^{2}$ Gandan (czyli Ich Chüree) oraz chińskiej „dzielnicy” handlowej (maimai cheng). Otaczały je jurty ${ }^{3}$, których właściciele w większości przybywali i zmieniali swoje miejsce pobytu, zgodnie z tradycją ludów koczujących. Po rewolucji 1921 r. architekci radzieccy opracowali nowe założenia urbanistyczne Ułan Bator. W rezultacie wybudowano miasto zgodnie $\mathrm{z}$ kanonami zabudowy socjalistycznego modernizmu ${ }^{4}$. Na skutek m.in. przymusowej relokacji ludności w latach pięćdziesiątych XX w. przez ponad dekadę stolica notowała rokrocznie skokowy, około dziesięcioprocentowy wzrost liczby ludności. Po 1965 r. wciąż trwał napływ migrantów do Ułan Bator, skutkujący przyrostem ludności o $2-4 \%$ w skali roku, który utrzymywał się jeszcze po transformacji ustrojowej. W końcu lat dziewięćdziesiątych Mongolia przeżyła serię klęsk żywiołowych - wyjątkowo surowych, śmiercionośnych warunków klimatycznych w sezonie zimowym (tzw. $d z u d$ ), co wpłynęło na wzrost i stabilizację dynamiki przyrostu ludności. Obecnie w stolicy mieszka 1,6 mln z 3,2 mln ogółu ludności kraju. Ze wzğlędu na potencjał demograficzny, lokalizację siedziby władz rządowych, słabą infrastrukturę całego kraju i brak innych silnych ośrodków miejskich znaczna część obrotu kapitału, inwestycje, $\mathrm{w}$ tym również $\mathrm{w}$ twardą infrastrukturę, skupione są $\mathrm{w}$ stolicy w skali raczej unikalnej na tle innych krajów Azji Wschodniej. W rezultacie podstawowy termin mongolski oznaczający ,miasto' (chot) odnosi się wyłącznie do Ułan Bator, a już nie do Kobdo, Czojbalsan, historycznego Uliastaj czy Karakorum oraz pogórniczego Darchan i Erdenet. Stolica zaś stała się niemal synonimem całego państwa mongolskiego. Ciągły napływ nowych imigrantów prawdopodobnie wpłynie na proces petryfikacji pozycji miasta, ponieważ nie ma wielu perspektywicznych miejsc, które mogłyby

2 W przeciwieństwie do Tybetu przedrewolucyjne klasztory Mongolii Północnej w większości również miały charakter koczowniczy i nie stymulowały powstawania trwałego osadnictwa.

3 Czyli ger, osiedla mieszkalne na planie koła, z domostwami przypominającymi namioty.

4 Jednak z częściowym utrzymaniem zabudowy rosyjskiej sprzed rewolucji. 
stanowić alternatywę dla walczących o przetrwanie migrujących obywateli w innych miejscach kraju ${ }^{5}$.

Migracja z terenów wiejskich jest globalnym trendem, ale prowadzący osiadły tryb życia postnomadowie zachowują swój charakterystyczny sposób myślenia, chociażby o strukturach nieformalnych ${ }^{6}$, co kształtuje tożsamość i praktyki społeczne ${ }^{7}$, które funkcjonują nawet po porzuceniu nomadyzmu i adaptacji do sfery miejskiej ${ }^{8}$.

Autorka książki wskazuje na mniej zauważalny aspekt migracji wewnątrz miasta, podczas gdy uwaga większości badaczy skupia się na masowym napływie ludności z prowincji. Nie jest to zawsze permanentne osadnictwo. Poza migrantami, którzy utracili stada w kataklizmach naturalnych czy na skutek dewastacji środowiska naturalnego i zmian klimatycznych, istnieje też ludność fluktuująca między miastem, miejscowością swojego ajmaku (województwa) oraz prowincją.

\section{Inna przestrzeń}

W publikacji analizowany był głównie okres lat 2016-2017 i przypadający na niego czas gwałtownej rozbudowy miasta. Efektem tego procesu było nasilanie się negatywnych ocen mieszkańców Ułan Bator na temat zachodzących zmian infrastrukturalnych i funkcjonalnych miasta. Przestało ono spełniać oczekiwania i zabezpieczać potrzeby ich znacznej części, gdyż nawet nowe osiedla często miały fundamentalne braki infrastrukturalne (s. 137). Publikacja australijskiej antropolożki wydaje się godna uwagi z co

5 Mongolia. From the steppe to the slum, dostępny w internecie, Al Jazeera, [dostęp: 13 I 2021]: <https://www.youtube.com/watch?fbclid=IwAR3ayPX4iuLPDvXP2plR1JR SYPY13TtXP3P4Z9v4cctflBbGXhzYDu3cR8U\&v=8x7wgiTnfCs\&feature=youtu.be $>$.

6 S. Szynkiewicz, Rodzina pasterska w Mongolii, Ossolineum, Wrocław 1981; Ch. P. Atwood., Banner, otog, thousand. Appanage communities as the basic unit of traditional Mongolian society, "Mongolian Studies" 2012, vol. 34, ; C. Humprey, D. Sneath, The end of nomadism? Society, state and the environment in Inner Asia, Duke University Press, Durham 1999, s. 15, 26-30.

7 B. Dulam, The state, popular mobilisation and gold mining in Mongolia. Shaping 'neoliberal' policies, UCL Press, London 2020, s. 9, 12.

8 Por. Studium przypadku chińsko-mongolskiego miasta Höhhot: W. R. Jankowiak, Sex, death and hierarchy in a Chinese city: an anthropological account, Columbia University Press, New York 1993, s. 1-19. 
najmniej kilku przyczyn. Autorka zauważa, że Ułan Bator to miasto bez koncepcji granic, byt ruchomy i transformujący się w kontekście procesów oddolnych. W rezultacie poza ścisłym centrum stolicy z radzieckim i potransformacyjnym budownictwem pod względem infrastruktury można wyróżnić jeszcze dwie strefy. Cechą szczególną Ułan Bator jest to, że większość miasta to suburbia pokryte głównie jurtowiskami (ger). Główny zaś kierunek rozwoju miasta wyznaczany jest przez "doczepianie się” i poszerzanie dzielnic zakładanych przez migrujących postnomadów. Mniej oczywiste jest powstawanie przestrzeni quasi-miejskiej, czyli eklektycznej strefy przejściowej (ögöömör) między centrum i jurtowiskami (s. 57-58). Składają się na nią przemieszane architektonicznie obszary suburbiów jurtowych, baraki robotnicze, centra usługowo-handlowe oraz różnej jakości budownictwo mieszkalne. Charakter urbanistyczny poza ścisłym centrum potęguje wrażenie liminalności samej przestrzeni miejskiej.

Możliwa staje się obserwacja, że strefy przejściowe ögöömör tworzą dynamiczną relację między tzw. centrum z trwałą zabudową a dzielnicami jurtowymi (geriin choroo) praktycznie pozbawionymi elementów miejskiej infrastruktury ${ }^{9}$. Wraz z ciągłym napływem migrantów do Ułan Bator miasto rozlewa się poprzez oddolną ekspansję, którą władze próbują ostatnio ograniczyć. Same strefy stały się główną areną wielkich szans i porażek, spekulacji oraz często teatrem nierównej walki między deweloperami a społecznościami jurtowisk o grunty i ewentualne rekompensaty za ich przejęcie (s. 83).

Dążąc do uzupełnienia tego studium zróżnicowania procesów gentryfikacyjnych jurtowisk i przede wszystkim stref przejściowych, dodałabym proces nazwany roboczo "gentryfikacją punktową", który jest skutkiem aktywności samych lokalnych wspólnot, a niekoniecznie ich wypieraniem z zajmowanych terenów przez deweloperów ${ }^{10}$.

9 Por. Mongolia. Internal migration study, Ger Community Mapping Center, Ulaanbaatar 2018; Mongolia. Urban migrant vulnerabiliy assessment, Ger Community Mapping, Ulaanbaatar 2018.

10 Por. K.Golik, The sedentarisation and gentrification in post-nomadic districts, "Prace Etnograficzne. Zeszyty Naukowe Uniwersytetu Jagiellońskiego" 2021, t. 49, nr 1-2: Kinship and urbanisation in Inner Asia, w ramach projektu "Kinship and Sedentarization in Central Asian Urban Areas of Hailar, Ulan-Ude and Ulaanbaatar", OPUS 13, 2017/25/B/Hs3/00675. 


\section{Posttransformacyjne problemy mieszkańców}

Publikacja wydaje się godna uwagi za sprawą wszechstronnego spojrzenia na problem rozwoju miasta z punktu widzenia jego mieszkańców. Studium to zawiera przede wszystkim opis ekonomiki budownictwa mieszkalnego z perspektywy antropologicznej, która łączy problematykę rozwoju infrastruktury mieszkaniowej z procesami społecznymi. Należy podkreślić, że badana była społeczność działająca $\mathrm{w}$ bardzo niestabilnym środowisku makroekonomicznym ${ }^{11}$, które cechuje posttransformacyjna niepewność w zakresie zatrudnienia czy uzyskania dochodów dających szansę na zakup mieszkania ${ }^{12}$. Autorka umiejętnie powiązała dynamikę transformacji przestrzennej i mobilizacji społecznej w reakcji na nią z przepływem kapitału, głównie w relacji Mongolii z Chinami.

Kluczowymi aspektami w rozwoju urbanistycznym Ułan Bator, na które wskazuje Plueckhahn, wydają się typ prawa do gruntów oraz ekonomia cyrkulacyjna, rozumiana w specyficznym, mongolskim kontekście wpływu sfery nieformalnej na oficjalne relacje ekonomiczne (s. 39-40), w tym politykę kredytów hipotecznych dla klasy średniej (s. 38-40). Stąd też cenny jest opis specyficznej polityki dostępności kredytów hipotecznych. Wskazuje m.in., że w niestabilnym mongolskim systemie finansów rynkowych (oraz osobistych) polityka rządowa, stabilizując oprocentowanie kredytów hipotecznych na poziomie $8 \%$ przy określonym poziomie wkładu własnego, zadziałała populistycznie $($ s. 34, 36) i „kupiła” ludzi aspirujących do klasy średniej.

$\mathrm{Na}$ marginesie dodam, że w Polsce można znaleźć pewne analogie w odniesieniu do podobnej grupy ludności, określanej obecnie jako tzw. frankowicze. Pośrednio w Mongolii uwidocznił się strukturalny problem relacji niskich płac do bardzo dynamicznie wzrastających cen nieruchomości,

11 Economic health index, ICBC, July 2017, s. 6; nt. "bliźniaczych deficytów" i innych nierównowag makroekonomicznych por. K. Golik, Dependent development of a frontier state - the case of Mongolia, Working Paper on East Asian Studies, University Duisburg-Essen, Duisburg [w druku w 2021], s. 32-36.

12 T. Rakowski, Przepływy współdziałania, kręgi możliwego. Antropologia powodzenia, Fundacja Terytoria Książki, Gdańsk 2019, s. 109-120; T. Rakowski, Lokalne formy rozwoju, samoorganizacja i potencjał sprawczy, "Kultura i rozwój" 2016, nr 1 (1), s. 91-93, 101-104; R. Empson, Subjective lives and economic transformations in Mongolia. Life in the gap, UCL Press, London 2020, DOI: https://doi.org/10.14324/111.9781787351462, s. 3-4. 
na co zareagował rząd i bank centralny. Zmusiły one banki komercyjne do liberalizacji polityki kredytowej, i to na sztywny, nierynkowy procent. W Polsce czy na Węgrzech natomiast rozluźniono kryteria przyznawania kredytów walutowych ze znanymi konsekwencjami. Z tym, że w Mongolii cyrkulacja finansowa znacznie silniej opiera się na powiązaniach nieformalnych, które ostatecznie kumulują się $w$ warunki otrzymania oficjalnego kredytu mieszkaniowego, choć nie zawsze przyznawany jest on z zachowaniem perspektywy procedur makroostrożnościowych.

W omawianej publikacji Plueckhahn opisała zróżnicowane zachowania graczy rynkowych $\mathrm{w}$ odniesieniu do zmian urbanistycznych i procesów strukturalnych ludności Ułan Bator, w tym przede wszystkim - firm deweloperskich. W tym przypadku również uwidacznia się szereg uniwersalnych mechanizmów, jednak czynnikiem specyficznym okazał się brak standardu wyceny gruntów pod budowę, co doprowadziło do różnicowania statusu i szans na rekompensaty dla dotychczasowych mieszkańców gentryfikowanych jurtowisk. Dopiero po pogorszeniu się koniunktury i schłodzeniu rynku nieruchomości, na którym, w moim przekonaniu, narosła bańka spekulacyjna ${ }^{13}$ większa niż $\mathrm{w}$ wielu miastach Chin, wartość ziemi stała się bardziej stabilnym kryterium, podobnie jak jej użytkowanie z pełnymi prawami właścicielskimi (ömczlöl) ${ }^{14}$, co również jest zagadnieniem nietrywialnym. Kwestia własności, dość jednoznacznie unormowana w prawodawstwie i praktykach społeczeństw zachodnich, w Mongolii pozostaje bardzo polisemiczna.

W publikacji przytoczone zostały przykłady ekstremalnych warunków panujących w blokach mieszkalnych, bez ogrzewania zimą czy wody latem. Dochodzi też do tego, że poziom zanieczyszczenia powietrza jest tak wysoki jak w najbardziej zanieczyszczonych metropoliach chińskich czy indyjskich ${ }^{15}$.

13 K. Golik, Dependent..., s. 37.

14 Które rynek traktuje tak jak prawo własności.

15 Na potrzeby niniejszego opracowania dokonałam analizy danych z bardzo niekompletnej bazy odczytów pomiarów powietrza WHO za lata 2010-2015. Dla Ułan Bator odczyt średniej rocznej dla PM10 to 165,1 , zaś PM2,5 to 75,1 . W bazie tej z 332 miast (razy liczba obserwacji - nie zawsze za cały okres pięciu lat) w Chinach i Indiach (często też znacznie większych od mongolskiej stolicy), w tym okresie wyższe średnioroczne wartości dla PM 10 odnotowano w miastolatach 28 razy, a dla PM 2,5 - 44 obserwacji miastolat (czyli jeśli np. miasto Wuhan w całym badanym okresie miało wyższe odczyty, to odpowiada ono za 5 obserwacji). Można zatem 
Położenie Ułan Bator w niecce, $\mathrm{z}$ bezwietrznymi zimami, skrajne ubóstwo energetyczne ludności (zimą biedne rodziny wydają na oǵrzewanie około $30 \%$ dochodów) oraz fakt, że jedyne efektywne arterie komunikacyjne przechodzą przez ścisłe centrum strukturalnie uniemożliwiają wprowadzenie znanych z innych miejsc rozwiązań tego problemu.

\section{Kultura a gospodarka}

Wychodząc od koncepcji normatywnych Mongołów, autorka porusza też szerokie spektrum problemów etycznych związanych z gwałtowną transformacją miasta na poziomie makro, jak też i odpowiedzialnością wobec rodu na poziomie najniższym (s. 41, 43, 92-94). Dochodzą do tego identyfikacje regionalne (związane z małą ojczyzną - nutağ) lub w obrębie grupy postapanażowej, etnograficznej lub etnicznej. Mongołowie posiadają szereg tradycyjnych struktur społecznych, które nie zawsze mają odpowiedniki pośród innych ludów koczowniczych (a tym bardziej osiadłych) ${ }^{16}$. Dodatkowo potrafią się one różnić nawet pomiędzy mongolskimi grupami etnicznymi, do których przynależność, nawet obecnie, wpływa na pozycję jednostki w społeczeństwie czy wręcz ją determinuje. Ponieważ nie mamy do czynienia ze względnie zunifikowanym, homogenicznym narodem, występuje także heterodoksyjność hierarchii w ramach samych rodów pomiędzy grupami etnicznymi, co w efekcie prowadzi do ewolucji odmiennych instytucji $\mathrm{w}$ ramach struktur społecznych grup krewniaczych. W literaturze używane

założyć, że Ułan Bator jest pod tym względem w czołówce najbardziej skażonych miast w Azji. Global urban ambient air pollution database (update 2016), WHO,

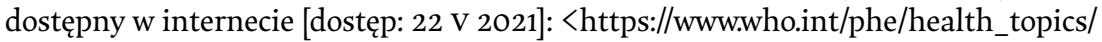
outdoorair/databases/cities/en/>.

16 Raphael Patai przedstawia zasadniczo listę przeciwstawnych cech: jurty kontra namioty, koczownictwo konne kontra mieszane pasterstwo itd. Konkluduje, że podstawowa różnica między stepami a pustynią ma związek z dominacją koczowniczego trybu życia w Azji Środkowej, podczas gdy na Bliskim Wschodzie „istnieje ścisła interakcja i współzależność grup koczowniczych i osiadłych". Ch. Lindholm, Kinship structure and political authority. The Middle East and Central Asia, "Comparative Studies in Society and History" 1986, vol. 28, no. 2, s. 335. Warto dodać, że ostatni element można uznać za co najmniej dyskusyjny, zważywszy że również w Azji Centralnej i Wewnętrznej gospodarka koczownicza była komplementarna z rolniczą lub miejską. 
jest co prawda określenie: „struktury klanowo-plemienne” ${ }^{\text {, }}$, jednak przy pogłębionej analizie procesów społeczeństw mongolskich należy mieć świadomość, że te koncepcje uchodzą w etnografii za bardzo przestarzałe i nie oddają stopnia skomplikowania nieformalnych struktur społecznych tej heterogenicznej nacji ${ }^{18}$.

Współcześnie w dalszym ciągu praktykowane jest wywodzące się z gospodarki pasterskiej czasowe użytkowanie dóbr, przede wszystkim pastwisk, głównie przez grupy rodowe ${ }^{19}$. Polega ono na tym, że różne gałęzie rodu (np. w ramach neg awyn chüüched - dosłownie: „dzieci jednego ojca”, co wskazuje na blisko spokrewnione struktury linieażowe) rotacyjnie użytkowały dane pastwisko i strzegły go przed obcymi rodzinami. Po pastwiskach również inne dobra mogły przechodzić z rąk do rąk, w zależności od potrzeb członków rodu. Koncepcja czasowego użytkowania stoi zatem w sprzeczności z własnością prywatną, co stanowi współcześnie przyczynę napięć społecznych. Z jednej strony współcześnie występuje koncepcja własności prywatnej ${ }^{20}$ (s. 108), z drugiej zaś powszechnie funkcjonuje wspomniana praktyka przechodniości dóbr ${ }^{21}$, obejmująca już z nie tylko pastwiska, ale też inne elementy majątku członków rodu. W warunkach

17 Ch. Lindholm, Kinship structure and..., s. 340-341.

18 Ibidem, s. 338-340.

19 To złożone zagadnienie w kontekście struktur społecznych kompletnie odmiennych od znanych ze społeczeństw europejskich, a nawet odmiennych od ludów chociażby w Azji Wschodniej było przedmiotem badań szeregu orientalistów w tym: A. Zhanaev, Kinship vs the relatedness of vitality in the Buryad-Mongol culture, [w:] Lokalne $i$ globalne perspektywy azjanistyczne - ksiegga jubileuszowa dla Profesora Sławoja Szynkiewicza, red. K. Baraniecka-Olszewska, I. Kabzińska, Oyungerel Tangad, IAiE PAN, Warszawa 2018 s. 213-221; S. Szynkiewicz, Rodzina pasterska w Mongolii, Ossolineum, Wrocław 1981; Ch. Atwood, Banner, Otog, Thousand. Appanage communities as the basic unit of traditional Mongolian society, "Mongolian Studies", The Mongolian Society, Bloomington 2012; C. Humprey, D. Sneath, The end of nomadism? Society, state and the environment in Inner Asia, Duke University Press, Durham 1999, 15, 26-30; A. Zhanaev, Alternative history: creation, use and interpretation of Buryat genealogies, [w:] Facing challenges of identification. Investigating identities of Buryats and their neighbor peoples, eds K. M. Wielecki, I. Peshkov, Wydawnictwa Uniwersytetu Warszawskiego, Warszawa 2020, s. 79-97.

20 Co jest nowością w regionie Azji Wschodniej i wszędzie utrudniają interpretację procesów mikro i makroekonomicznych.

21 T. Rakowski, Przeplywy..., s. 91-95, 151-155, 263-264. 
postnomadycznych elementy systemu myślenia, w którym owa własność nie była domeną jednostki, odwzorowują się w formule miasta i jego rozwoju. Świat idei wpływa też na prawodawstwo, jak regulacje dotyczące gruntów z 1994 r. (s. 16). Porównując typy użytkowania gruntów, należy wskazać na „stopniowanie własności”, czyli faktyczne lub efektywne użytkowanie oraz nominalne właścicielstwo (s. 103-104).

Koncepcja czasowego użytkowania dóbr oraz szereg kulturowych uwarunkowań procesów gospodarczych w Mongolii stanowią interesujący temat dla antropologów, który był wielokrotnie podejmowany w literaturze przedmiotu. Wartością dodaną omawianej publikacji jest włączenie analizy lokalnego świata idei w najbardziej aktualne procesy urbanizacyjne w mieście-państwie. Przede wszystkim jednak prezentuje ona znacznie szersze spojrzenie na procesy gospodarcze i administracyjne niż wydane niedawno i świetnie przyjęte przez antropologów studia Rebekki Empson ${ }^{22}$ czy Tomasza Rakowskiego ${ }^{23}$. Z tej przyczyny wydaje się mniej hermetyczna oraz może być ona interesująca nie tylko dla badaczy w ramach wąskiej dyscypliny, ale również dla eksploratorów innych dziedzin życia społecznego $\mathrm{w}$ państwach posttransformacyjnych oraz tych ze znaczącymi migracjami wewnętrznymi. Ponadto Autorka nie nasyca treści efektownymi konstruktami teoretycznymi, lecz koncentruje się na realnych procesach, umiejętnie wskazując na te kluczowe.

\section{Uwagi krytyczne}

Wartościowe podejście do analizy tematu ma też ewidentnie braki i słabe strony. Uwagi nie umniejszają wartości samej książki, jednak pewne korekty, w moim odczuciu, znacząco podniosłyby wartość publikacji.

Autorka, opisując niektóre procesy gospodarcze, nie odnosi ich do teorii ekonomicznych, aparat pojęciowy jest, co prawda, wzbogacany przez jej dorobek antropologiczny, ale nie ma precyzyjnych opisów oraz charakterystyk numerycznych zjawisk. Brakuje minimalnego choćby ilościowego zarysu omawianych procesów, pomimo że dane z różnych obszarów

22 R. Empson, Subjective...

23 T. Rakowski, Przepływy... 
społeczno-gospodarczych są łatwo dostępne. Po lekturze książki czytelnik może nadal nie być świadomy skali opisywanych problemów.

Pewnej sprzeczności w książce można się dopatrzyć w deklaracji koncentracji na warstwie społecznej o średnich dochodach. Jest to grupa ciekawa, gdyż zamieszkująca zarówno centrum, jak i jurtowiska, mająca także perspektywy mobilności przestrzennej oraz w zakresie mieszkalnictwa. W publikacji nie zostało przedstawione metodologiczne uzasadnienie i kryteria wyboru tej grupy. Z drugiej strony osoby wskazywane przez autorkę jako „klasa średnia” w moim rozumieniu raczej stanowią prekariat, jak np. wędrowni robotnicy na czasowych kontraktach czy osoby trwale imające się prac dorywczych. Całkowicie zaś pominięto kryteria określenia tej warstwy, co może być właśnie wynikiem jednak niedostatecznego pogłębienia zagadnień stricte ekonomicznych. Z tej przyczyny cenny empirycznie materiał staje się raczej reporterską relacją, a nie głębszą, interdyscyplinarną refleksją na temat procesów społeczno-gospodarczych. W ten sposób zaprezentowane zostało podejście antropologiczne do badania realnych procesów, ale też jego ograniczenia względem innych dyscyplin, takich jak socjologia czy ekonomia.

W publikacji ujęto zróżnicowanie instytucji, relacji między nimi oraz wielość czynników, których drobiazgowy opis wymagał zastosowania warsztatu badacza terenowego i umiejętności opisu fragmentarycznej rzeczywistości. Wynikał on też częściowo ze specyfiki instytucji publicznych tego państwa, w tym złego planowania przestrzennego. Przy tym trudno się zgodzić, że jest to nowy koncept w Mongolii (s. 10), gdyż za czasów socjalistycznych takie projekty, i to wysokiej jakości, powstawały. Uwzględniały chociażby obszary zielone i sadzenie drzew wzdłuż ważnych ulic - ostatnie z nich wycinano na moich oczach w latach 2006-2007. Autorka koncentruje się na pracach urbanisty wykształconego w Japonii, pomija zaś poprzednie pokolenia absolwentów Politechniki Irkuckiej (i innych radzieckich uczelni technicznych), które to miasto budowały. Wyraźnie zabrakło dłuższej perspektywy historycznej w spojrzeniu na rozwój miasta, jakby liczyło się tylko „nowe”. A przecież Ułan Bator w znacznej części bazuje na architekturze i infrastrukturze poradzieckiej, opisywana zaś przez autorkę bonanza deweloperska dotyczy głównie terenów wcześniej niezurbanizowanych lub jurtowisk.

Istotne jest wskazanie na relacje klientelistyczne lub klientalne (czyli współzależności pomiędzy patronami i grupami od nich zależnymi) i ich 
znaczenie gospodarcze $\mathrm{e}^{24}$. Niestety, Autorka na marginesie i bez wyjaśnień wspomina o specyfice tego uwarunkowania, stwierdzając jedynie, że skutkuje ono „fraktalnym charakterem własności gruntów” (s. 106). Ten fragment jest zupełnie niejasny, można tylko spekulować, czy nawiązuje do fascynujących procesów instytucjonalnych znanych z Azji Wschodniej ${ }^{25}$, czy jest to jakieś specyficzne spojrzenie na nieopisany w literaturze, wyjątkowy model relacji społecznych państwa mongolskiego.

Istotnym mankamentem książki jest zaniechanie w badaniach pogłębienia kwestii ekonomiki nieformalnej. W kontekście opisywanych zjawisk poważną lukę stanowią przede wszystkim analizy trzeciego funkcjonującego typu zadłużenia, dotyczącego osób w najtrudniejszej sytuacji, czyli klientów firm pożyczkowych i lombardów. I to w sytuacji podkreślania przez Autorkę różnych mechanizmów finansowania. Rodziny (zwykle migrantów i często w dzielnicach jurtowych) bez szans na uzyskanie kredytu w oficjalnej instytucji bankowej (sfera formalna), jednocześnie nie posiadając sieci społecznego wsparcia (sfera nieformalna), sięgają po środki z firm lichwiarskich, tworzących sektor shadow banking - niebezpieczny zarówno dla jednostek, jak i - potencjalnie - dla gospodarki, o czym przekonały się boleśnie znacznie bogatsze i bardziej rozwinięte miasta chińskie, jak np. Wenzhou ${ }^{26}$. Pewnym rozczarowaniem jest de facto brak głębszego odniesienia do perspektyw rozwojowych miasta (s. 155-157), które niedługo może zamieszkiwać praktycznie cała populacja kraju.

\section{Perspektywy rozwojowe}

Lektura książki pozwala zidentyfikować uniwersalne mechanizmy relacji władzy i pieniądza manifestujące się w stepowym entouragéu (s. 43, 105-6, 110, 150). Następnie uwidaczniają się strukturalne bolączki ekonomiczne

24 Por. też. A. W. Hedwig, The financialization of help: moneylenders as economic translators in the debt-based economy, "Central Asian Survey" 2018, vol. 37, no. 3, , s. 219-222.

25 Dla Chin por. K. Gawlikowski, Problem ustroju współczesnych Chin, [w:] Prasa chinska o przemianach społecznych $i$ kulturowych kraju w początkach XXI wieku, red. K. Gawlikowski i in., Wydawnictwo Akademickie SEDNO, Warszawa 2020, s. $133-145$.

26 Lerong Lu, Shadow banking for cash-strapped entrepreneurs. A study of private lending agreements under Chinese contract law, "Journal of Business Law" 2018, issue 3, s. 216-229. 
społeczeństw dawnego bloku wschodniego, które polskiemu czytelnikowi mogą wydać się znajome, a przez to też interesujące przy porównaniu różnych ułomnych prób rozwiązań problemów typowych dla krajów postkomunistycznych. Jednak boom urbanistyczny, jaki przeżywa Mongolia, wyrósł na specyficznym gruncie kulturowym, który jak wielokrotnie wykazano w książce, bezpośrednio wpływa na system ekonomiczny.

Opisywane miasto jest tworem idei postnomadów z ich rozwiązaniami prawnymi i praktykami administracyjnymi, organizacją przestrzeni, jurtowiskami oraz strukturami społecznymi. Przy takiej, a nie innej organizacji państwa i trendach gospodarczych możemy się spodziewać migracji zdecydowanej większości mieszkańców Mongolii i dalszego wzrostu niewydolności aparatu administracyjnego w zderzeniu z tym procesem. Miasto przyszłości to nie tylko wysokościowce, ale też petryfikacja statusu części jurtowisk - quasi-zurbanizowanych w swym charakterze - oraz rozwój w kierunku budownictwa w substandardzie. Te dystrykty, niby-miasta, to sfera, która zapewne będzie się transformować, ale niekoniecznie w kierunku najbardziej oczywistych wyobrażeń o nowoczesnej metropolii. 